\title{
Ethics in Nanomedicine: A Concern on New Nanotechnology
}

\author{
Viroj Wiwanitkit ${ }^{1,2,3,4^{*}}$ \\ ${ }^{1}$ Visiting professor, Hainan Medical University, China; \\ ${ }^{2}$ Visiting professor, Faculty of Medicine, University of Nis, Serbia; \\ ${ }^{3}$ Adjunct professor, Joseph Ayobabalola University, Nigeria; \\ ${ }^{4}$ Honorary professor Dr DY Patil University, India.
}

${ }^{*}$ Correspondence: Professor Viroj Wiwanitkit, Wiwanitkit House, Bangkhae, Bangkok Thailand. Email: wviroj@yahoo.com

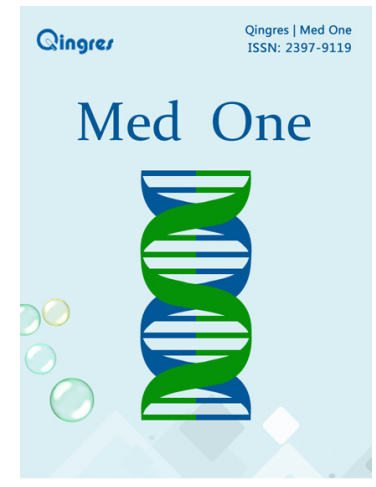

http://mo.qingres.com

\section{GOPEN ACCESS}

DOI: 10.20900/mo.20170025

Received: July 26, 2017

Accepted: September 29, 2017

Published: October 25, 2017

Copyright: @2017 Cain et al. This is an open access article distributed under the terms of the Creative Commons Attribution License, which permits unrestricted use, distribution, and reproduction in any medium, provided the original author and source are credited.
There are many new emerging technologies, including to nanotechnologies. Those technologies can be useful for daily life. Indeed, nanotechnologies have been developed for a few years, but they are presently widely used. As a new technology, controlling is needed. There are many concerns on the effectiveness, efficacy, cost and safety but there is limited consideration on misconduct and misuse of the nanotechnology. The ethical issue is an important concern for any new technologies that is usually forgotten. Jameel noted that "great advances in technology produce unique challenges. Every technology also has a dual use, which needs to be understood and managed to extract maximum benefits for mankind and the development of civilization ${ }^{[1]}$." We cannot overlook the possible adverse consequences of any new technologies that can be problematic, harmful or dangerous. If it is illegally or unethically used without control, the new technology can be an unwanted danger.

"Why we have to concern on nanotechnology ethics?" is a simple question. Dalton-Brown noted that "Upstream engagement is commonly regarded as necessary for the smooth implementation of new technologies, particularly when there is an impact on health [2]." Without ethical control, unwanted problem can result from the uncontrolled use of nanotechnology. There must be a code of conduct for dealing with nanotechnology.

Indeed, the international collaboration regarding ethics for nanotechnology is required. To achieve a sustainable management of the implementation of new nanotechnologies, both scientific and humanistic regulations are required ${ }^{[3]}$. An ethical problem regarding the nanotechnology might be a new thing and forgotten, but it is an important issue in present era of emerging nanotechnology. Both ethical and legal controls have important roles for harmonizing the use of new emerging nanotechnologies in nanomedicine ${ }^{[4]}$. There are 
many important questions regarding nanotechnology ethics ${ }^{[5-10]}$ (Table 1). Those new questions become interesting queries for further "thinking and sharing" among practitioners regarding new nanomedical technology.

Table 1. Interesting questions on nanotechnologies related ethics

\begin{tabular}{ll}
\hline Authors & Details \\
\hline & $\begin{array}{l}\text { Carvalho et al. }{ }^{[5]} \text { asked an interesting question "how can ethics relate to science?" } \\
\text { Carvalho et al. concluded that "The current bioethics debates of emerging }\end{array}$ \\
situations (pluripotent stem cells, gene therapy, nanotechnology) have undoubtedly \\
contributed to this change ${ }^{[5] . "}$
\end{tabular}

Casado and Buxo ${ }^{[6]}$ asked an interesting question "What challenges offers nanotechnology to bioethics?" Casado and Buxo gave a discussion that "science Casado and Buxo ${ }^{[6]} \quad$ and morality are closely linked and complementary. That is, technology, society and morality, by themselves, do not have the absolute truth and must be complemented among them without any of the three being suppressed ${ }^{[6]}$."

Lupton ${ }^{[7]}$ discussed on several applications of new nanotechnologies for human Lupton $^{[7]}$ beings including to the use of nanomedicine. Lupton raised a concern that "problem areas stemming from the technology include the following - Who will benefit - just the rich or the poor as well? ${ }^{[7]}$

Parr $^{[8]}$

Parr raised an interesting philosophic question "Will nanotechnology make the world a better place? ${ }^{[8] "}$

Rasmussen and Ebbesen raised and discussed on educational issue regarding nanotechnology. The interesting question is "why should nanoscience students be

Rasmussen and Ebbesen $^{[9]}$ taught to be ethically competent? ${ }^{[9] "}$ Rasmussen and Ebbesen concluded "it is seen that the dilemma can have more than one solution and that ethical competence can help in justifying the choice of solution in a specific situation ${ }^{[9]}$."

Sylvester and Bowman discussed on patenting regarding new nanotechnology ${ }^{[10]}$. Sylvester and Bowman raised an interesting question "whether the current patent landscape will be able to withstand the ubiquitous nature of the technology, or whether nanotechnology will be a catalyst for governments and policy makers for overhauling the current landscape design ${ }^{[10]}$."

Sylvester and Bowman ${ }^{[10]}$

For nanomedicine, the general rule of medical ethics must be applied ${ }^{[11]}$. At present, ethical dilemma on nanomedicine technology exists. The new technique might be the hope for management of complex disease whereas it can induce adverse effect on the other hand ${ }^{[11]}$.

As noted by King, "Risks of harm, translational uncertainty, ambiguities in potential direct benefit, and long-term follow-up merit consideration in first-inhuman research ${ }^{[12]}$." The first human nanomedicine trial and further use of newly nanomedicine therapeutic technologies directly violate this principle. With lack for complete data at present, there is no information on nanomedical technologies for the patients and there will be no complete informed consent. Long-term impact of unethical nanotechnology research might result in several unwanted problems such as carcinogenesis and mutagenesis due to nanomedical particle exposure. In addition, the unethical practitioner might use the 
non-proven nanomedical therapy for management of their patients aiming at making profit. Unregistered nanomedical drug is considered illegal but it has been widely used by several unethical practitioners ${ }^{[11,}$ ${ }^{13]}$. This is not an uncommon problem in developing countries $^{[13]}$.

In addition, to the unethical use of nanomedicine in medical practice, the problem on nanomedicine research and publication also exists. Indeed, there are many interesting case studies on unethical nanomedicine researches which confirm the urgent requirement for controlling ${ }^{[13-14]}$. Misconducts in nanomedicine research can be seen in several ways (fabrication, falsification a plagiarism). At present, many new nanopharmacy companies support the nanomedicine trials that are considered first human studies which are ethical challenges ${ }^{[12,15]}$. The conflict of interest, privacy and confidentiality will be the important concerns in rapid growth of nanomedicine research. The proof of nanotoxicology is needed for any new nanotechnologies to confirm the "helping without harm" paradigm of nanomedicine ${ }^{[16]}$. Finally, the already developed technologies also pose ethical issues on patenting ${ }^{[17]}$.

It is no doubt that the problem will increase in the nearly future since there is a rapid growth of nanomedicine. For future perspective, the specific international ethical standards for nanomedicine will be set up and correspond to the urgent requirement for control of nanomedicine. This will be the future hope for good clinical and ethical practice in nanomedicine.

\section{CONFLICTS OF INTEREST}

There are no conflicts of interest.

\section{REFERENCES}

1. Jameel S. Ethics in biotechnology and biosecurity. Indian J Med Microbiol. 2011; 29: 331-335.

2. Dalton-Brown S. Public Engagement and Nanotechnology in Australia. Camb Q Healthc Ethics. 2016; 25: 518-525.

3. Toth-Fejel TT. Humanity and nanotechnology-judging enhancements. Natl Cathol Bioeth Q. 2004; 4: 335-364.

4. Byk C. Nanomaterials and the environmental risk: is there some room left for ethics and law? J Int Bioethique. 2011; 22: 157-172, 216.
5. Carvalho AS, Ramalho-Santos J. How can ethics relate to science? The case of stem cell research. Eur J Hum Genet. 2013; 21: 591-595.

6. Susanne C, Casado M, Buxo MJ. What challenges offers nanotechnology to bioethics? Rev Derecho Genoma Hum. 2005; 22: 27-45.

7. Lupton M. Nanotechnologysalvation or damnation for humans? Med Law. 2007; 26: 349-362.

8. Parr D. Will nanotechnology make the world a better place? Trends Biotechnol. 2005; 23: 395398.

9. Rasmussen AJ, Ebbesen M. Why should nanoscience students be taught to be ethically competent? Sci Eng Ethics. 2014; 20: 10651077.

10. Sylvester DJ, Bowman DM. Navigating the patent landscapes for nanotechnology: English gardens or tangled grounds? Methods Mol Biol. 2011; 726: 359-378.

11. Yasri S, Wiwanitkit V. Important ethical issues for nanomedicine. J Res Med Sci. 2017 (in press).

12. Patil M, Mehta DS, Guvva S. Future impact of nanotechnology on medicine and dentistry. J Indian Soc Periodontol. 2008; 12(2): 34-40.

13. Panda JJ, Yandrapu S, Kadam RS, Chauhan VS, Kompella UB. Retracted: Self-assembled Phenylalanine- $\alpha, \beta$-dehydrophenylalanine Nanotubes for Sustained Intravitreal Delivery of a Multi-targeted Tyrosine Kinase Inhibitor. J Control Release. 2016; 237: 186.

14. Retraction Statement: "High-Volumetric Performance Aligned Nano-Porous Microwave Exfoliated Graphite Oxide-based Electrochemical Capacitors" and "Aligned NanoPorous Microwave Exfoliated Graphite Oxide Ionic Actuators with High Strain and Elastic Energy Density". Adv Mater. 2016; 28: 9453.

15. Bawa R, Johnson S. The ethical dimensions of nanomedicine. Med Clin North Am. 2007; 91: 881-887.

16. Shvedova AA, Kagan VE. The role of nanotoxicology in realizing the 'helping without harm' paradigm of nanomedicine: lessons from studies of pulmonary effects of single-walled carbon nanotubes. J Intern Med. 2010; 267 : 106-118.

17. Manchikanti P, Uppala S, Bonta RK. Patents in Nanobiotechnology: A Cross Jurisdictional Approach. Recent Pat Biotechnol. 2017; 11(1): 52-70. 